\title{
Repeatability and reproducibility of body condition score in Yankasa sheep
}

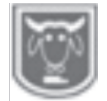

Ma'aruf, B. S., Maigado, A. I., Shuaibu, A. and Umar, H. A.

Department of Animal Science, Faculty of Agriculture, Federal University of Kashere, Gombe State, Nigeria

Abstract

Body condition score is very critical during breeding, lambing and lactation, the current study was conducted to assess the repeatability and reproducibility of body condition score inYankasa sheep in some selected Local Government Areas of Kano State, Nigeria; Bebeji (BBJ), Dawakin Kudu (DKD), Wudil (WDL), Shanono (SNN), and Dambatta (DBT). Multistage sampling was adopted to select a total of 300 sheep comrison of 99 rams and 201 ewes. Body condition score was determined twice a day by two assessors using the standard procedure. The experiment was conducted using a cross factor design. Model III analysis of variance was carried out to determine the between sheep and inter and intra-assessor variations in the trait. The results shows a significant $(P<0.01)$ effects of rams and ewes on the body condition score.It is concluded that repeatability and reproducibility of BCS were very high (0.828-0.982 and 0.791-0.939 for repeatability and reproducibility, respectively). It is recommended that sheep farmers consider condition scores in the selection and routinely assess their animals' nutritional status.

Keywords:, Repeatability, Reproducibility, Sheep, Body Condition Score

\section{Répétabilité et reproductibilité du score de l'état corporel chez les moutons Yankasa}

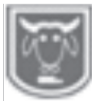

\section{Résumé}

Le score de l'état corporel est très critique pendant la reproduction, l'agnelage et la lactation, la présente étude a été menée pour évaluer la répétabilité et la reproductibilité du score de l'état corporel chez les moutons de Yankasa dans certaines zones de gouvernement local sélectionnées de l'État de Kano, au Nigeria; Bebeji (BBJ), Dawakin Kudu (DKD), Wudil (WDL), Shanono (SNN) et Dambatta (DBT). Un échantillonnage à plusieurs degrés a été adopté pour sélectionner un total de 300 moutons de 99 béliers et 201 brebis. Le score de l'état corporel a été déterminé deux fois par jour par deux évaluateurs en utilisant la procédure standard. L'expérience a été menée en utilisant une conception à facteurs croisés. Une analyse de la variance du modèle III a été effectuée pour déterminer les variations entre les moutons et les variations inter et intra-évaluateur du caractère. Les résultats montrent un effet significatif $(P<0,01)$ des béliers et des brebis sur le score de l'état corporel. Il est conclu que la répétabilité et la reproductibilité du BCS étaient très élevées (0,828-0,982 et 0,7910,939 pour la répétabilité et la reproductibilité, respectivement). Il est recommandé aux éleveurs de moutons de prendre en compte les scores de condition dans la sélection et d'évaluer régulièrement l'état nutritionnel de leurs animaux.

Mots clés: répétabilité, reproductibilité, mouton, score de l'état corporel

\section{Introduction}

Body condition scoring in sheep estimates the muscle and fat cover of the animal by palpation of different regions of the body. It is done by accurate palpation of the lumbar region around the backbone in the loin area immediately behind the last rib (13th-14th) and above the kidneys. In contrast to cows and goats, wool in sheep makes it challenging to assign the score (Gaias, 


\section{Repeatability and reproducibility of body condition score in Yankasa sheep}

2012). Body condition at the time of breeding and lambing can affect the performance of ewes and lambs and productivity. Studies have reported direct impacts of ewe body condition score (BCS) on reproductive performance (Y1lmaz et al., 2011), colostrum production (Jalilian and Moeini, 2013), survival, and growth rates of lambs (Sar1 et al., 2013; CornerThomas et al., 2015). The usefulness and reliability of a BCS are dependent on 3 aspects: repeatability, reproducibility, and predictability. Repeatability is an assessor's ability to assign the same score for the same animal during repeated examinations, provided the animal's body condition has not changed (William, 2000). Repeatability is an assessment of within-assessor variability or within-assessor precision. In other words, the ability of two or more assessors to assign the same score for the same animal independently. Reproducibility is an assessment of between-assessor variability or betweenassessor precision. Reproducibility also indicates the likelihood that all parties in a discussion understand the animal's body condition when a BCS is stated and the associated consequences of that BCS in regard to the desired goal for that animal. Predictability is the BCS's ability to reflect an animal's actual body components (William, 2000). Therefore, it isessential to routinely assess the condition score of sheep and determine the scoring procedure's reliability. The reliability of body condition score depends on its repeatability and reproducibility, as such the current study aimed at evaluating the repeatability and reproducibility of body condition score in Yankas sheep in Kano state.

\section{Materials and methods}

The study was carried out in some selected Local Government Areas (LGAs) of Kano State, namely, Shanono, Dawakin Kudu,
Bebeji, Wudil, and Dambatta. Multistage sampling was adopted in the study. The first stage involved selecting five LGAs (Shanono, Dawakin Kudu, Bebeji, Wudil, and Dambatta) based on their suitability for sheep production, market, and road access, and willingness of people to participate. The second stage involved the purposive selection of two villages from each LGAs, making a total of ten villages. The third stage entailsthe identification and selection of six households from each village that kept at least ten sheep. The fourth stage was the random selection of five sheep from each selected household, making a total 300 sheepcomrison of 201 ewes and 99 rams. The data for this research was collected from November 2015 to March 2016. Condition score was done while the animals were standing upright and relaxed in a normal posture. It was carried out by two assessors twice a day (8;00-10am and 4:006:00pm, using the system of Abebe (2009) used in sheep based on a scale of 0 to 5 . Assessors remained blinded to the previous scores and did not discuss study results. The experiment was conducted using a cross factor design. Model III analysis of variance was carried out to determine the between sheep and inter and intra-assessors variations in BCS. Repeatability which is the proportion of the score variance attributable to scoring variation by the same assessor, and reproducibility, the score variance attributable to scoring variation by different assessors, were calculated using the method described by Jansen et al. (1985), using the following model:

$$
\begin{aligned}
& \mathbf{Y}_{i j k}=\mu+A_{i}+a_{j}+s_{k}+(A a)_{i j}+ \\
& (A s)_{i k}+(a s)_{j k}++_{e i j k} \\
& \text { Where: } \\
& Y_{i j k}=\text { body condition score on the } \\
& \mathrm{i}^{\text {th }} \text { animal by the } \mathrm{j}^{\text {th }} \text { assessor for the } \mathrm{k}^{\text {th }} \\
& \text { score } \\
& \mu=\text { overall mean } \\
& A_{i}=\text { effect of the } \mathrm{i}^{\text {th }} \text { animal }(i= \\
& 1 . . \mathrm{n}) \quad
\end{aligned}
$$




$$
\begin{aligned}
& a_{j}=\text { effect of the } \mathrm{j}^{\text {th }} \text { assessor }(j \\
& s^{k}=\text { effect of the } k^{\text {th }} \text { score } \\
& (A a)_{i j}=\text { interaction of the } \mathrm{i}^{\text {th }} \text { animal }
\end{aligned}
$$

with the $\mathrm{j}^{\text {th }}$ assessor

$(A s)_{i k}=$ interaction of the $\mathrm{i}^{\text {th }}$ animal with the $\mathrm{k}^{\text {th }}$ score

$(a s)_{j k}=$ interaction of the $\mathrm{j}^{\text {th }}$

assessor with the $\mathrm{k}^{\text {th }}$ score

$$
{ }_{e j i k}=\text { error term }
$$

Ve) / $\mathbf{V}_{\text {Total }}$

$$
\text { Repeatability: } r 1=\left(V_{\text {Total }}-\mathrm{Vs}\right. \text { - }
$$

Reproducibility: $r 2=\mathrm{V}_{\mathrm{A}} / \mathrm{V}_{\text {Total }}$

Where: $\mathrm{V}_{\mathrm{A}}, \mathrm{v}_{\mathrm{a}}, \mathrm{v}_{\mathrm{s}}, \mathrm{v}_{\mathrm{Aa}}$ and $\mathrm{v}_{\mathrm{e}}$ are the variance components of $A_{i} a_{j}, s_{k}(A a)_{i j}$, $(A s)_{i k},(a s)_{j k}$ and eijk, respectively.and the total variance $\mathrm{V}_{\text {Total }}=\mathrm{v}_{\mathrm{A}}+\mathrm{v}_{\mathrm{a}}+\mathrm{v}_{\mathrm{s}}+\mathrm{v}_{\mathrm{Aa}}+$ $\mathrm{v}_{\mathrm{As}}+\mathrm{v}_{\mathrm{as}}+\mathrm{v}_{\mathrm{e}}$

\section{Results and discussion}

Table 1 presents the analysis of variance, calculated variance components, repeatability $\left(r_{1}\right)$ and reproducibility $\left(r_{2}\right)$ of body condition scoring in $<1$-year rams. There were highly significant $(\mathrm{P}<0.001)$ effects of ram on BCS, also the interaction between ram and assessor was significant $(\mathrm{P}<0.001)$. However, the assessor and score did not exhibit any significant influence on the trait. The estimated components of variance were $0.264,0.002,0.000,0.024$, and 0.026 , respectively, for the ram, assessor, score, ram $\mathrm{x}$ score, and error component. The repeatability and reproducibility estimates of BCS were 0.917 and 0.835 , respectively.

Analysis of variance, calculated variance components, repeatability $\left(\mathrm{r}_{1}\right)$ and reproducibility $\left(\mathrm{r}_{2}\right)$ of body condition scoring in 1-3 years ram are depicted in Table 2. There were highly significant $(\mathrm{P}<0.001)$ effects of ram as well as that of the interaction between ram $\mathrm{x}$ assessor and ram $\mathrm{x}$ score $(\mathrm{P}<0.01)$ on $\mathrm{BCS}$. However, the assessor and score did not exert any considerable influence on the character. The estimated components of variance were $0.254,0.000,0.000,0.017,0.017$ and 0.033 , respectively for ram, assessor, score, ram $\mathrm{x}$ score and error component. The values of repeatability and reproducibility of the character were 0.897 and 0.719 , respectively.

Table 3 shows the analysis of variance, calculated variance components, repeatability $\left(r_{1}\right)$, and reproducibility $\left(r_{2}\right)$ of body condition scoring in $<1$-year ewe. Ewe and assessor had a significant $(\mathrm{P}<0.01)$ effect on BCS, whereas the score is not significant. The estimated variance components were $0.198,0.009,0.000$, and 0.043 for ewes, assessor, score, and error components. The repeatability and reproducibility estimates were 0.828 and 0.792 , respectively.

Table 1: Analysis of variance, calculated variance components, repeatability $\left(r_{1}\right)$ and reproducibility $\left(\mathbf{r}_{2}\right)$ of body condition scoring in $<1$ year ram

\begin{tabular}{lccccc}
\hline Source of Variation & DF & MS & Est. of Var. Comp. & r1 & r2 \\
\hline Ram & 38 & $1.129^{* * *}$ & 0.264 & 0.917 & 0.835 \\
Assessor & 1 & $0.231^{\mathrm{NS}}$ & 0.002 & & \\
Score & 1 & $0.026^{\mathrm{NS}}$ & 0.000 & & \\
Ram x Assessor & 38 & $0.073^{* * *}$ & 0.024 & \\
Error & 77 & 0.026 & 0.026 & \\
\hline Total & 155 & 1.485 & 0.316 & \\
\hline DF= degree of freedom, MS= mean square, ${ }^{* * *}=\mathrm{P}<0.001$, NS not significant
\end{tabular}


Repeatability and reproducibility of body condition score in Yankasa sheep

Table 2:Analysis of variance, calculated variance components, repeatability $\left(\mathbf{r}_{1}\right)$ and reproducibility $\left(r_{2}\right)$ of body condition scoring in 1-3years ram

\begin{tabular}{lccccr}
\hline Source of Variation & DF & MS & Est. of Var. Comp. & r1 & r2 \\
\hline Ram & 59 & $1.119^{* * *}$ & 0.254 & 0.897 & 0.791 \\
Assessor & 1 & $0.067^{\mathrm{NS}}$ & 0.000 & & \\
Score & 1 & $0.000^{\mathrm{NS}}$ & 0.000 & & \\
Ram x Assessor & 59 & $0.067^{* *}$ & 0.017 & & \\
Ram x score & 59 & $0.068^{* *}$ & 0.017 & & \\
Error & 60 & 0.033 & 0.033 & & \\
\hline Total & 239 & 1.354 & 0.321 & & \\
\hline $\mathrm{DF}=$ degree of freedom, $\mathrm{MS}=$ mean square, ${ }^{* *}=\mathrm{P}<0.01, * * *=\mathrm{P}<0.001$, NS not significant &
\end{tabular}

Table 3:Analysis of variance, calculated variance components, repeatability $\left(\mathrm{r}_{1}\right)$ and reproducibility $\left(r_{2}\right)$ of body condition scoring in $<1$ year ewes

\begin{tabular}{lccccc}
\hline Source of Variation & DF & MS & Est. of Var. Comp. & r1 & r2 \\
\hline Ewe & 13 & $0.835^{* * *}$ & 0.198 & 0.828 & 0.792 \\
Assessor & 1 & $0.286^{* *}$ & 0.009 & & \\
Score & 1 & $0.000^{\mathrm{NS}}$ & 0.000 & & \\
Error & 40 & 0.043 & 0.043 & & \\
\hline Total & 55 & 1.164 & 0.25 & & \\
\hline $\mathrm{DF}=$ degree of freedom, $\mathrm{MS}=$ & mean square, ${ }^{* *}=\mathrm{P}<0.01, * * *=\mathrm{P}<0.001$, NS not significant &
\end{tabular}

Analysis of variance, calculated variance components, repeatability $\left(\mathrm{r}_{1}\right)$, and reproducibility $\left(\mathrm{r}_{2}\right)$ of body condition scoring in 1-3 years ewes are depicted in Table 4. There were highly significant $(\mathrm{P}<0.001)$ effects of ewes, ewes $\mathrm{x}$ score, and score $\mathrm{x}$ assessor interactions, whereas assessor and score failed to exert any considerable influence on the trait. The estimated components of variance were $0.538,0.001,0.001,0.016,0.001$, and 0.048 for ewes, assessor, score, ewes x score, score assessor, and error component, respectively. The values of repeatability and reproducibility of the trait were 0.919 and 0.889 , respectively.

Table 4:Analysis of variance, calculated variance components, repeatability $\left(r_{1}\right)$ and reproducibility $\left(r_{2}\right)$ of body condition scoring in $1-3$ years ewes

\begin{tabular}{lccccc}
\hline Source of Variation & DF & MS & Est. of Var. Comp. & r1 & r2 \\
\hline Ewe & 126 & $2.234^{* * *}$ & 0.538 & 0.919 & 0.889 \\
Assessor & 1 & $0.096^{\mathrm{NS}}$ & 0.001 & & \\
Score & 1 & $0.569^{\mathrm{NS}}$ & 0.001 & \\
Ewes x Score & 126 & $0.018^{* * *}$ & 0.016 & \\
Score x Assessor & 1 & $0.238^{*}$ & 0.001 & \\
Error & 252 & 0.048 & 0.048 & \\
\hline Total & 507 & 3.203 & 0.605 & & \\
\hline
\end{tabular}

$\mathrm{DF}=$ degree of freedom, $\mathrm{MS}=$ mean square, $*=\mathrm{P}<0.05, * * *=\mathrm{P}<0.001$, NS not significant

Table 5 shows the analysis of variance, calculated variance components, repeatability $\left(r_{1}\right)$, and reproducibility $\left(r_{2}\right)$ of body condition scoring in $>3$ years ewes. There were highly significant $(\mathrm{P}<0.001)$ effects of ewe and ewes $\mathrm{x}$ score interaction as well as that of the score $(\mathrm{P}<0.05)$.
However, the effect of the assessor was negligible. The estimated components of variance were $0.637,0.000,0.003,0.030$, and 0.008 , respectively for ewes, assessor, score, ewes x score, and error component, while the repeatability and reproducibility of the character were 0.984 and 0.939 . 
Table 5:Analysis of variance, calculated variance components, repeatability $\left(r_{1}\right)$ and reproducibility $\left(r_{2}\right)$ of body condition scoring in $>\mathbf{3}$ years ewes

\begin{tabular}{lccccc}
\hline Source of Variation & DF & MS & Est. of Var. Comp. & r1 & r2 \\
\hline Ewe & 59 & $2.616^{* * *}$ & 0.637 & 0.984 & 0.939 \\
Assessor & 1 & $0.017^{\mathrm{NS}}$ & 0.000 & & \\
Score & 1 & $0.417^{*}$ & 0.003 & & \\
Ewes x score & 59 & $0.069^{* * *}$ & 0.030 & & \\
Error & 119 & 0.008 & 0.008 & & \\
\hline Total & 239 & 3.127 & 0.678 & & \\
\hline DF $=$ degree of freedom, MS $=$ mean square, ${ }^{*}=\mathrm{P}<0.05, * * *=\mathrm{P}<0.001$, NS not significant
\end{tabular}

\section{Discussion}

A number of factors determine the animal's body condition status, most of which are related to nutrition, but to some extent, the physiological state plays an important role. The current research revealed a positive impact of an animal on its condition score. This is expected as the judgment is conducted on the same day, so the animal's nutritional state may not significantly change regardless of their age group and sex. The significant interactions of animals with their assessors or score indicated that the differences varied according to the level of animal condition score with the greatest variation at high and low condition score. This gives an insight to the fact that the score was actually for the animals, and the assessor worked with the same animals. Audigeet al. (1998) reported similar findings on red deer hinds. The repeatability and reproducibility of BCS in this research were found to be very close to one. The high value of repeatability showed the ability of the assessors to capture the actual condition score of an animal up to $98 \%$, and the reproducibility, which ranged from 0.791 0.939 , indicates the agreement of different assessors in capturing the actual score of a given animal up to $93 \%$. A report similar to this was made by Audige et al. (1998), however, Evans (1978) reported lower values in cattle.

\section{Conclusion}

The current work revealed a practical body condition score system to be used in sheep. The study shows that BCS is a valuable tool for investigating the adequacy of management practices, and it is a simple, repeatable, and reproducible system. Sheep farmers should consider condition scores in the selection and routinely assess their animals' nutritional status using the repeatability of the condition score.

\section{References}

Abebe, G. 2009. Technical Bulletin No. 8: Body condition scoring of sheep and goats. Ethiopia Sheep and Goat Productivity Improvement Program (ESGPIP). Ethiopia

Audige, L., Wilson, P.R., and Moris, R.S., 1998. A Body Condition Score System and its Use for Farmed Red Deer Hinds. New Zealand Journal of Agricultural Research, 41:545553

Corner-Thomas, R. A., Back, P. J., Kenyon, P. R., Hickson, R. E., Ridler, A. L., Stafford, K. J., and Morris, S. T. 2015. Ad libitum pasture feeding in late pregnancy does not improve the performance of twin-bearing ewes and their lambs, Asian Australas, Journal of Animal Science. 28, 360-368,

Evans, D. G. 1978. The Interpretation and Analysis of Subjective Body Condition Scores. Animal Production 26:119-125

Gaias, G. 2012. Body Condition Score and Body Composition of Sarda dairy ewes $\mathrm{Ph} \mathrm{D} \mathrm{th}$ e sis, UniversitaDegliStudi Di Sassari, Sassari, Italy, $138 \mathrm{pp}$. 
Jalilian, M. T. and Moeini, M. M. 2013. The effect of body condition score and body weight of Sanjabi ewes on immune system, productive and reproductive performance. ActaAgra. Slovenica, 102, 99-106,.

Jansen, J., Bech Andersen, B., Bu, H., $L$ a g e $r$ w e i j, G. W., a nd Oldenbroek, J.K 1985 Invivo Estimation of the Body Composition in Young Bulls for Slaughter, The Repeatability and Reproducibility of a Scoring System, an Ultrasonic Scanning Te chnique and Body Measurements. Livestock Production Science 12:221-230
Sarı, M., Önk, K., Aksoy, A. R., and Tilki, M . $\begin{array}{llll}2 & 0 & 1 & 3\end{array}$ Tujkoyunlarındadogumkondisyon puanınınkuzularınbüyümeözellikl erive ya,samagücüneetkisi, F.Ü. Sag. Bil. Vet. Derg., 27, 149-154,

William, J. B. 2000. Use of Body Condition Scores in Clinical Assessment of the Provision of Optimal Nutrition. Journal of Agriculture and Veterinary Medicine, 217:5

Yılmaz, M., Altın, T., Karaca, O., Cemal, 'I., Bardakçıoglu, H. E., Yılmaz, O. and Ta, skın, T. 2011. Effect of body condition score at mating on the reproductive performance of Kivircik sheep under an extensive production system, TropicalAnimal Health and Production. 43, 1555-1560,

Received: $12^{\text {th }}$ October, 2020 Accepted: $19^{\text {th }}$ February, 2021 